\title{
Demographic Profile of Knee Osteoarthritis Patients in a Teaching Hospital West Java, 2013
}

\author{
Tranggana Nugrahaputra, ${ }^{1}$ Tertianto Prabowo, ${ }^{2}$ Henny Anggraini Sadeli ${ }^{3}$ \\ ${ }^{1}$ Faculty of Medicine Universitas Padjadjaran, ${ }^{2}$ Department of Physical Medicine and \\ Rehabilitation, Faculty of Medicine Universitas Padjadjaran/Dr. Hasan Sadikin General Hospital \\ Bandung, ${ }^{3}$ Department of Neurology Faculty of Medicine Universitas Padjadjaran/Dr. Hasan \\ Sadikin General Hospital Bandung
}

\begin{abstract}
Background: Osteoarthritis is the most common degenerative musculoskeletal diseases occur worldwide. It usually affects the weight-bearing joint such as knee and vertebra. Osteoarthritis is influenced by various risk factors. The aim of the study was to identify the demographic profile of knee osteoarthritis patients. Methods: A retrospective descriptive study was performed to 247 medical records of knee osteoarthritis patients who attended to Physical Medicine and Rehabilitation of Dr. Hasan Sadikin General Hospital Bandung in 2013. The inclusion criteria were medical records that consisted of age, sex and occupation of the patients, and payment methods. Exclusion criteria were incomplete of the necessary data mentioned in the inclusion criteria. The study was conducted from August until November 2014. The collected data were analyzed and presented using frequency distribution.

Results: From all the patients, $40.9 \%$ was $60-69$ years old, $77.7 \%$ were women and $82.6 \%$ were retired patients. Most of the patients had a social health insurance.

Conclusions: Majority of patients is 60-69 years old women, retired and has the financial protection. [AMJ.2015;2(4):597-600]
\end{abstract}

Keywords: Demographic profile, knee osteoarthritis, social health insurance

\section{Introduction}

Osteoarthritis is one of arthritic diseases which frequently causes a chronic musculoskeletal pain and movement disability to the elder in worldwide. ${ }^{1}$ Knee osteoarthritis is influenced by various factors, such as age, sex, genetic factor, obesity, metabolic diseases, joint injury, activity that involved cumulative pressure on joints, and vigorous exercise. Sign and symptoms of osteoarthritis are joint edema, pain, local warmness, crepitation, and movement limitation. ${ }^{2}$

Osteoarthritis frequently affects weight bearing joints. The most common weight bearing joint is affected by osteoarthritis is knee. ${ }^{3}$ The prevalence of knee osteoarthritis is two times higher than hip osteoarthritis in people over 60 years old. ${ }^{4}$ Around 35\% people over 65 years old suffers from knee osteoarthritis. $^{5}$ Knee osteoarthritis cases require to be treated for a period of time and can cause financial implication. During the last two decades, Indonesia implements a health payment restructuration by developing a social-health insurance. ${ }^{6}$ The existence of this health insurance can provide a financial protection for the patients so they can get their treatment regularly.

Knowing the demografic profile of the patients is considerably important in managing the disease. The aim of the study was to identify the demographic profile of knee osteoarthritis patients.

\section{Methods}

This study was performed using a retrospective descriptive design. A number of 247 medical records on knee osteoarthritis patients was collected. The inclusion criteria were medical records of knee osteoarthritis patients in Physical Medicine and Rehabilitation Policlinic of Dr. Hasan Sadikin General Hospital Bandung in 2013. It consisted of age, sex and occupation of the patients, and also the payment methods.

Correspondence: Tranggana Nugrahaputra, Faculty of Medicine, Universitas Padjadjaran, Jalan Raya BandungSumedang Km.21, Jatinangor, Sumedang, Indonesia, Phone: +62811236349 Email: twentyfivefour@yahoo.com 


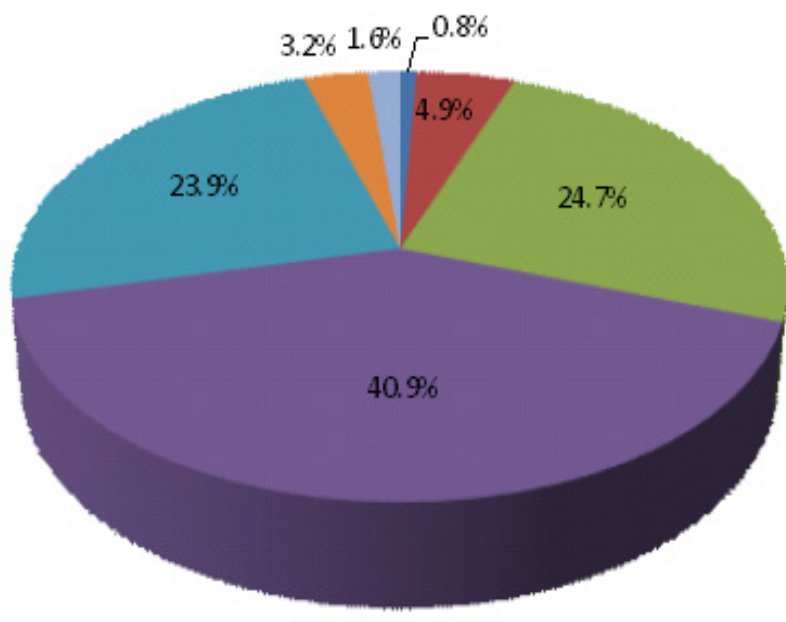

- 30 - 39 years old

ロ40- 49 years old

-50- 59 years old

-60- 69 years old

n $70-79$ years old

- 80 - 89 years old

- 90 - 99 years old

Figure 1 vistribution oi knee usteoartnritis ratients accoraing to Age

An exclusion criterion was incomplete the necessary data mentioned in the inclusion criteria. The study was conducted from August until November 2014.

This study had been approved by Health Research Ethics Committee of Dr. Hasan Sadikin General Hospital Bandung and Faculty of Medicine, Universitas Padjadjaran. The collected data were analyzed and presented using a frequency distribution.

\section{Results}

The collected medical records that met the inclusion criteria were 247 medical records. Patient profiles were classified by age, sex, occupation, and payment methods.

The most common age group of patient in Physical Medicine and Rehabilitation Policlinic of Dr. Hasan Sadikin General Hospital due to knee osteoarthritis was those who were 6069 years old, followed by $50-59$ years old and 70-79 years old. Moreover, female patients were higher than male (3.5:1) and most of the patients were retired. (Table 1)

From all of the payment methods, most of the patients had protected from financial burden either by health insurance or by

Table 4 Reasons for Ideal Age of Marriage and Childbearing

\begin{tabular}{lcc}
\hline \multicolumn{1}{c}{ Characteristics } & n & \% \\
\hline Sex & & \\
Male & 55 & 22.3 \\
Female & 192 & 77.7 \\
Occupation & & \\
$\quad$ Still working & 43 & 17.4 \\
$\quad$ Retired & 204 & 82.6 \\
Payment methods & & \\
Civil Servants of Social Health Insurance & 192 & 77.7 \\
National Social Health Insurance (Jaminan Kesehatan & 9 & 3.6 \\
Masyarakat, Jamkesmas) & 34 & 13.8 \\
Payment by Company/Firm & 12 & 4.9 \\
Out-of-Pocket Payment & & \\
\hline
\end{tabular}


company payment, yet, there was still a small group of patients that paid their care by themselves.

\section{Discussion}

Knee osteoarthritis was one of the leading disability causes in worldwide.4 From this study, it is found that most of the patients were above 60 years old. This result was similar to the study conducted by Nur Aslyn et $\mathrm{al}^{4}{ }^{4}$ stated that knee osteoarthritis prevalence raise twofold on population above 60 years old. Yoshimura et al. ${ }^{7}$ on his study conducted in Japan, stated that knee osteoarthritis prevalence was most common (57.1\%) on 6069 years old age group. ${ }^{7}$ There are 61 patients on 50-59 years old age group, (24.7\%) which made this age group as the second age group with numerous knee osteoarthritic patient, which is quite interesting. Squatting and sitting above limb performed every day, and praying procedure may causes the knee osteoarthritis development on younger age. Moreover, most of the patients are female. In line with a study conducted by Kusuma et al. ${ }^{8}$, it is stated that women were more frequent $(66.2 \%)$ found to attend Medical Rehabilitation Clinic. Women have a further risk factor to be suffered from osteoarthritis due to the reduced estrogen level in menopause; which in the end, estrogen are important to delay the bone resorption.

Retired patients are easily found in this study $(82.6 \%)$ compared to those who are still working $(17.4 \%)$. It is possibly caused by the majority of respondent characteristic which mostly had exceeded his/her productive age, in addition to frequent of squatting that could overwhelm the knee joint burden. Conversely Andriyasa's ${ }^{9}$ study states that only $16.7 \%$ of patient who were not working suffered from knee osteoarthritis.

Most of the patients have one of the financial schemes either by social insurance or company/firm payment. Hidayat et al. ${ }^{10}$ states that this health insurance can expand the patient's accesibility to health care. The existence of insurance has many benefits. Knee osteoarthirtis patients could attend frequent rehabilitation in the hospital, in addition to drugs need to be consumed periodically without worrying about money they should prepared before coming to the hospital

During this study, there are several limitations that possibly influence the results. One of them is the incomplete data in the patient's medical records.

It can be concluded that the demografic profile of knee osteoarthritis patients are above 60 years old, mostly female, retired and have the social health insurance.

A further study should be conducted on clinical and sociodemographic profile of knee osteoarthritis, especially the risk factors , since there are lots of factor that could influence the disease.

\section{References}

1. Zhang W, Moskowitz R, Nuki G, Abramson $\mathrm{S}$, Altman $\mathrm{R}$, Arden $\mathrm{N}$, et al. OARSI recommendations for the management of hip and knee osteoarthritis, Part II: OARSI evidence-based, expert consensus guidelines. Osteoarthritis Cartilage. 2008;16(2):137-62.

2. Yekti RP, Mutiatikum D. Faktor-faktor yang berhubungan dengan penyakit sendi berdasarkan RISKESDAS di Indonesia 2007-2008. Bul Penelit Kesehat. 2009; 37(Suppl):32-9.

3. Hui AY, McCarty WJ, Masuda K, Firestein GS, Sah RL. A systems biology approach to synovial joint lubrication in health, injury, and disease. Wiley Interdiscip Rev Syst Biol Med. 2012;4(1):15-37.

4. Nor Aslin MN, Su Lyn K. Effects of passive joint mobilization on patients with knee osteoarthritis. Sains Malaysiana. 2011;40 (12):1461-5.

5. Tarigan T, Kasjmir YI, Atmakusuma D, Lydia A, Bashiruddin J, Kusumawijaya K, et al. The degree of radiographic abnormalities and postural instability in patients with knee osteoarthritis. Acta Med Indonesia. 2009;41(1):15-9.

6. Aji B, De Allegri M, Souares A, Sauerborn R. The impact of health insurance programs on out-of-pocket expenditures in Indonesia: An Increase or a Decrease? Int J Environ Res Public Health. 2013;10(7):2995-3013.

7. Yoshimura N, Muraki S, Oka H, Mabuchi A, En-Yo Y, Yoshida M, et al. Prevalence of knee osteoarthritis, lumbar spondylosis, and osteoporosis in Japanese men and women: the research on osteoarthritis/ osteoporosis against disability study. J Bone Miner Metab. 2009;27(5):620-8.

8. Kusuma W, Angliadi E, Angliadi L. Profil penderita osteoartritis lutut dengan obesitas di Instalasi Rehabilitasi Medik Rumah Sakit Umum Pusat Prof. Dr. R. D Kandou Manado. Jurnal e-Clinic (eCl). 2014;2(3):1-4.

9. Andriyasa K, Putra TR. Korelasi antara derajat beratnya osteoartritis lutut dan 
cartilage oligometric matrix protein serum. J Penyakit Dalam. 2012;13(1):11-20.

10. Hidayat B, Thabrany H, Dong H, Sauerborn R. The effects of mandatory health insurance on equity in access to outpatient care in Indonesia. Health Policy Plan. 2004;19(5):322-35. 